\title{
O ESPETÁCULO DA HUMILHAÇÃO, FISSURAS E LIMITES DA SEXUALIDADE
}

María Elvira Díaz-Benítez

Humilhação ou humiliation porn é um segmento do mercado do fetiche que reúne adeptos ao longo do planeta. Basta clicar nestas palavras-chave no Google para comprovar o enorme leque de possibilidades que se abre para os interessados. Alguns desses sites remetem a estéticas que no mundo pornô são conhecidas como kink e que fazem alusão mais direta ao universo BDSM. Outros se abrem a práticas diversas divulgadas como punishment, sex slave e, em menor medida, rape. Alguns links levam a sites de Taboo, modo como são divulgados filmes com a temática do incesto, enquanto outros remetem a filmes de bestial porn, que inclui práticas de humilhação com animais.

Orgias, gang bangs, duplas, ménage à trois, ou o que for, são diversas as modalidades e arranjos dentro do universo da humilhação, cuja principal característica é a força extrema na realização das práticas, indicando a dominação de um (ou uns) sobre outro(s). Embora grande parte das práticas na humilhação se encaixe naquilo que reconhecemos nas convenções do sexual, muitas delas abrem mão da nudez dos corpos, das penetrações e de qualquer interação com as genitálias, limitando-se a exercícios de infligir dor ou asco.

Esta é uma etnografia sobre a produção da humilhação. Apresento aqui resultados da pesquisa que realizei em 2011 e 2012 junto a uma produtora desse tipo de material em uma cidade latino-americana de grande porte. Opto por não localizar nem caracterizar melhor os sujeitos da pesquisa como uma maneira básica de resguardar suas identidades. Neste artigo, concentro-me basicamente na análise das práticas, excluindo dados etnográficos sobre as relações e a sociabilidade no set de filmagem ou as biografias dos sujeitos.

O objetivo que atravessa as descrições a seguir é o exame de formas com que atua a violência no erotismo, ou melhor, os modos, no âmbito do erotismo, com que se intersectam o prazer e o perigo (Vance 1984; Rubin 2011; Califia 1994; Facchini 2008; Gregori 2010; Sáez \& Carrascosa 2012; Garcia 2009). Esta é, então, uma etnografia de práticas que usam a dominação, os espancamentos, os engasgamentos e as sufocações em gramáticas comer- 
ciais de dor, medo e nojo quase sempre feitas em duplas de mulheres que representam a relação dominadora/escrava. Nesse arranjo, são articulados diversos marcadores sociais da diferença, colocando-se em cena convenções eróticas nas quais os tensores libidinais — classe, geração, estilo e raça (Perlongher 1987) - operam na organização do desejo. Em meio a enredos que evocam hierarquias sociais, como a relação patroa/empregada, que é, de fato, o mais comum nessas performances, juntam-se mulheres grandes e altas ao lado de mulheres baixas e miúdas, ou mulheres mais velhas com mulheres de aparência muito jovem. A diferença mais evidente é de tamanho, visando evidenciar claramente a existência de um desequilíbrio de forças.

As práticas de humilhação extrema trazem desafios teóricos interessantes. Levando em conta que as novas formas de erotismo colocam o consentimento como base legítima para a realização e a legitimação das práticas e que muito do que se entende por direitos sexuais parte deste pressuposto, interessaria pensar na dupla prazer/violência para além da chave do consentimento? Ou seja, estamos falando de práticas consentidas no sentido de que são feitas por uma produtora na qual as pessoas - sempre maiores de idade - são informadas do trabalho que deverão realizar e assinam contratos. Contudo, por se tratar de erotismos com características extremas do uso da força, são boas para pensar os limites da sexualidade, entendidos como "a zona fronteiriça onde habitam norma e transgressão, consentimento e abuso, prazer e dor" (Gregori 2010:3).

\section{Uma contemporânea ostentação do suplício}

No fetiche produzido hoje nesse país encontramos majoritariamente práticas associadas à adoração de uma parte do corpo, especialmente pés. Um pé que pode ser o centro das atenções em um ato de dominação/sujeição leve, no qual o escravo beija, lambe, acaricia seu próprio rosto, se devota às atenções ao pé da dominadora, sendo o pé o fio condutor de práticas que mobilizam prazer para ambos os envolvidos na relação - o que é considerado um feetlove - ou um pé que domina com violência, que esmaga, pisa e bate, sendo estes últimos os fetiches que acompanhei.

Nas cenas relativas a este tipo de dominação, geralmente a escrava jaz de joelhos, enquanto a dominadora, em pé, dá-lhe chutes no rosto. É comum também que a primeira esteja deitada com a boca pra cima para ser pisada no rosto pela dominadora, ou que seja forçada bruscamente a chupar o pé, ou que este esmague a sua cabeça contra o chão. As mudanças nas disposições e nas intensidades levam a que as práticas recebam adjeti- 
vos como extreme, excessive, dangerous ou dirty. Por vezes, as escravas são imobilizadas com cordas ou envolvidas em plástico para assegurar sua total imobilização enquanto os pés espancam ou são introduzidos — pelo lado dos dedos ou do calcanhar - na sua boca para causar sufocação, engasgamento ou vômito. Nas práticas em que os pés estão sujos, a escrava deve lambê-los entre chutes e puxões de cabelo.

Em atos mais extremos, os pés oprimem com força os pescoços das escravas, projetando a ideia de se estar exercendo humilhações excessivas e simultaneamente perigosas. Em outros, as escravas são obrigadas, em meio a agressões, a comer os resíduos de pele que caem do calcanhar da dominadora quando este é limado, ou a engolir as unhas dos pés que as dominadoras cortam e que são colocadas direto em suas bocas, ou a lamber meias sujas e suadas. Apenas uma prática é reservada à "submissão voluntária" por parte da escrava, na qual ela lambe e suga os pés da dominadora que jaz adormecida. Existe ainda outro ato em que, totalmente imobilizada, a escrava recebe cosquinhas da dominadora que, ao serem feitas com diferentes intensidades, força e agressividade, podem assumir contornos de tortura. Finalmente, destinam uma única prática, que inclui dominação, agressividade e penetrações, à presença de um homem, que se junta à dupla de mulheres.

Entre as práticas destinadas especificamente à sufocação, a mais valorizada é aquela conhecida no mercado mundial do fetiche como face sitting. Neste, as dominadoras sentam sobre os rostos das escravas obstruindo seus orifícios respiratórios com suas nádegas e vaginas. A ideia consiste em sufocar ao extremo usando para tanto batidas e movimentos agressivos. Quando a prática assume tons mais violentos, recebe o adjetivo extreme. Nesta modalidade utilizam-se ademais outros métodos de sufocação: enfiar com força a cabeça da escrava num tanque com água ou em sacos plásticos, por exemplo. Ou então fazer uso de duas dominadoras contra uma única escrava. São efetuadas outras práticas, que consistem em impedir a respiração da escrava, obstruindo bruscamente seus narizes e bocas através das mãos das dominadoras. Os adjetivos excessive e danger são usados também quando as práticas consistem em obstruir a respiração e simultaneamente engasgar a escrava, enfiando a outra mão em sua garganta o mais profundo possível, às vezes até causar o vômito. Em outra modalidade de sufocação são utilizadas as pernas da dominadora que, com força, apertam a cabeça e o pescoço da escrava como se fossem tesouras, causando rendição e imobilidade. Em uma versão de práticas de sufocação com sexo penetrativo, geralmente um homem intervém na cena, ou em sua ausência são executadas penetrações vaginais na escrava com mãos e punhos, como no fistfucking. 
Existe ainda um terceiro tipo de fetiches que podem ser classificados como práticas de socar e de resistência de peso. Entre estes, um dos mais produzidos é o trample, que consiste em pisar e pisotear a escrava. Quando se adicionam pulos da dominadora sobre o corpo da escrava, o fetiche é denominado trample and jump (ou trampling jumping), como é conhecido no mercado internacional. Este é considerado pelos produtores um dos fetiches de maior risco e possui uma versão extrema na qual os pulos são efetuados não em pé, mas com o corpo sentado para que a bunda da dominadora bata com força no estômago ou na cabeça da escrava. Outros fetiches de resistência de peso consistem em tomar o escravo como uma poltrona ou sofá. No ato, a dominadora (ou um grupo de duas ou três mulheres) senta sobre o corpo da escrava para ler um livro, falar ao telefone, insultá-la ou simplesmente descansar. A ideia é humilhar a escrava, fazendo-a passar por um objeto e simultaneamente causando-lhe dor e sufocação por meio do peso. Em outro estilo, a dominadora obriga a escrava a deslocar-se pelo espaço de quatro carregando-a nas costas como se fosse um cavalo. Neste fetiche utilizam-se escravas magrelas e pequenas transportando dominadoras grandes ou mesmo gordas. A ideia da humilhação se constrói em função do uso da pessoa como um animal de carga.

Existem ainda fetiches baseados exclusivamente no ato de socar, seja por meio de tapas e chutes, seja com o punho fechado diretamente no estômago. A estes últimos, somam-se outros que também insistem na subjugação do escravo, em obrigá-lo a executar ou a receber um ato a contragosto. O mais leve consiste no ato de obrigar a escrava a cheirar as axilas da dominadora. Quando o adjetivo fuck é adicionado, o fetiche traz longas sequências de uma escrava fazendo sexo oral em um ou mais homens, terminando a maior parte das vezes com a ejaculação dos mesmos. Em outro, o uso da força e do insulto tem como objetivo obrigar a escrava a comer, abrindo sua boca com agressividade para enchê-la exageradamente de comida, causando, às vezes, náuseas e vômito. Ou então, a escrava é obrigada a engolir o cuspe que várias dominadoras jogam contra seus rostos ou diretamente dentro de suas bocas por meio de um funil, enquanto ela permanece deitada, imobilizada, ou é obrigada a lamber um chão cheio da saliva de diferentes dominadoras. Se no mercado internacional de forced lesbian ou lesbian forced é comum encontrar o cenário do sexo forçado ou o estupro de mulheres em presídios, no caso desta produtora trata-se de fetiche em que uma mulher (mais velha, mais gorda, mais alta ou maior) força uma escrava a beijá-la, lambê-la ou fazer nela sexo oral. Já no Farting, a escrava é obrigada a receber em seu rosto os peidos da dominadora e a enfiar seus rosto e nariz em seu ânus. 
Scat é a abreviatura em inglês de scatology ou escatologia. É um fetiche considerado nesse meio como de máxima humilhação: o tope de todas as humilhações possíveis. Consiste no ato de obrigar a escrava a receber em sua boca, e em alguns casos a engolir, as fezes de uma ou mais dominadoras. Na produtora existem variações de scat, o mais extremo sendo denominado de diarreia. No mercado internacional o scat é também conhecido como caviar ou caviar experience, o que guarda relação com uma expressão que escutei em campo: "o maior presente que uma rainha pode dar a uma escrava é seu mais puro caviar". Finalmente, são produzidas cenas de sexo e dominação entre duas pessoas que pertencem à mesma família. As duplas mais procuradas pela empresa são pares de irmãs ou mãe e filha. Nesses casos, a escrava é sempre a filha ou a irmã mais nova, a qual é forçada pela dominadora (sua mãe ou irmã mais velha) a beijá-la e a fazer sexo oral, entre outras práticas. O mais importante neste tipo de cena é que as pessoas sejam verdadeiramente família, e que o sexo seja agressivo para passar a ideia de que o nojo e a humilhação da escrava são reais.

Como é possível observar nessa breve descrição das práticas, a força, a violência, a dominação e a sujeição são relevantes na composição do fetiche e atuam em função de organizar as disposições segundo a lógica da humilhação. Esta categoria, por sua vez, é a peça-chave na produção do desejo. A humilhação é gerada para o prazer dos consumidores. Entre eles e os produtores se estabelece um pacto comercial, que consiste em fazer com que a escrava sinta uma degradação real: quando ela apanha, é preciso que o soco ecoe com força, deixe marcas na pele, leve às lágrimas, enfim, que existam evidências de que nada ali é fake, pois os enganos são rapidamente percebidos e imediatamente rechaçados pelos clientes, para os quais a violência é um tensor libidinal.

Estamos falando, então, de dois tipos de duplas que se configuram através dessas produções. Aquela relativa ao binômio dominadora/escrava, e a relativa a produtor/consumidor. É nesta última que se assina o contrato do realismo, de modo que dominadoras e escravas atuam em função desse contrato.

Transmitir uma ideia de realismo implica, para os produtores, vigiar de forma minuciosa detalhes de diversas ordens: aqueles relacionados com as práticas em si e aqueles que compõem as poéticas do cenário e dos corpos. Não é à toa que a produção não investe em cenografias elaboradas (como é feito em grande parte no pornô e no universo kink) e que as pessoas usam em cena roupas que insinuam o dia a dia. A humilhação que eu conheci inventa a si mesma como o universo do prosaico, e daí derivam suas personagens mais frequentes: patroa e empregada doméstica, mãe e filha etc. que, somado 
à ausência de glamour, contribui para fazer reais seus enunciados. Para os produtores, responder e respeitar o contrato do realismo empreendido com seus clientes significa "dar satisfação", o que implica uma negociação mais ou menos estrita.

Os produtores veem nos consumidores pessoas possuidoras de perícias particulares, que não se deixam enganar facilmente e cujos gostos particulares os levam a pertencer a uma espécie de confraria. Os produtores mais reconhecidos no ramo do fetiche, no país pesquisado, se percebem a si mesmos como pertencentes a esse grupo seleto de conhecedores e assíduos do fetiche. Também por isso desenvolvem a obrigação de responder com seriedade às imposições de tal estética. Quer dizer, não há humilhação se ela não parecer real, e esse parecer real começa a ser construído na minúcia.

Para dar alguns exemplos, quando um consumidor deseja um pé sujo, o produtor entende que se trata de um pé sujo mesmo. Eles acreditam que os consumidores sabem reconhecer muito bem quando se trata de um pé que foi sujado estrategicamente para a cena, ou quando o pé, de fato, já estava sujo. Reprovam aquelas produtoras que utilizam pó de café, por exemplo, para emporcalhar rapidamente um pé, em vez de colocar a atriz para caminhar sem sapatos algum tempo sobre um chão empoeirado. Um pé limpo, recém-lavado é, segundo seu entender e olhar, muito diferente de um pé limpo que não foi lavado há pouco; um pé suado porque usou sandália é distinto de um pé que suou dentro de uma bota; consumidores que demonstram gosto por chulé sabem que a produção não pode transmitir diretamente o cheiro característico do chulé, mas exigem que o pé esteja úmido e amassado, de modo que possa transmitir visualmente essa sensação; procura-se que mãe e filha ou irmãs para uma cena de incesto, além de serem fenotipicamente similares, sejam realmente consanguíneas, pois só assim se torna possível atingir uma humilhação reconhecida como real. Uma vez os cenários, os sujeitos e seus corpos tenham sido dispostos e constituídos segundo esses modelos do real, o investimento recai nas práticas.

O fato de que exista a obrigação de que a humilhação seja real nos leva a perguntar o que é entendido como real nesse pacto e até onde? Trata-se de um acordo no qual, por momentos, não é mais a representação do ato, mas o ato mesmo que se procura para ser consumido? Como é produzida a humilhação?

Pesquisando filmagens pornográficas em outro contexto de pesquisa, eu percebi que as transas, em si, obedeciam a um esquema ou estilo ritualizado de se fazer sexo que se caracterizava por conservar uma ordem ou sequência nas posições sexuais desempenhadas e um tempo específico para cada uma delas. Chamei esse estilo de sexo coreográfico, o qual se compu- 
nha de beijos ardentes, sexo oral, sexo vaginal, terminando em sexo anal. As atrizes e os atores aprendiam tanto as sequências como as posições em que deviam desempenhar cada uma das práticas, pois o sexo respeita esse repertório restrito de possibilidades (Díaz-Benítez 2010).

A execução dos fetiches, ao contrário, não obedece a um script estabelecido. Tanto as dominadoras como as escravas recebem instruções e passam a reconhecer quais são as práticas que devem ser realizadas, mas não existe uma ordem ou sequência estrita na qual elas devam acontecer. Isto também tem a ver com a procura do realismo da representação: quanto mais espontâneo parecer e for menos possível distinguir uma coreografia, mais próximo do real o fetiche está. Assim, as dominadoras vão desenvolvendo os atos guiadas pelos seus impulsos, e as escravas vão respondendo paulatinamente ao comando da dominadora. Os diretores participam ativamente da organização da performance: eles guiam a cena de acordo com o que desejam projetar e criam os arranjos respeitando seu conhecimento das técnicas de cada fetiche, mas especialmente correspondendo à intensidade e ao clima que cada cena suscita. Assim, se, por exemplo, uma prática de sufocação com as mãos está sendo muito bem realizada pela dominadora e a reação da escrava é concomitante com a força performativa colocada pela primeira, os diretores podem insistir em manter uma longa sequência desse ato ou repeti-lo um maior número de vezes durante a cena.

Se existisse um script específico, o ato - tal como qualquer representação teatral - também estaria predisposto às emoções pessoais específicas de cada experiência, ao feeling entre os performers e à interação com a plateia. Mas certamente o fato de não existir uma coreografia estrita abre maiores espaços para a espontaneidade, a improvisação e a energização das intensidades. Então, quando as dominadoras e as escravas recebem instruções sobre como realizar as práticas, elas conseguem ter uma noção ampla do que está por vir, mas não têm a capacidade de prever até onde as práticas as levarão no âmbito das sensações. As escravas sabem que serão humilhadas, isto é, que será representada uma humilhação na qual elas são o alvo, mas não necessariamente imaginam que a sensação dessa humilhação possa ser sentida na pele de um modo real. Elas sabem que certos atos causarão dor, mas não conseguem antecipar quanto, em grande parte porque cada performance cria sua própria atmosfera, seu próprio fôlego e sua própria acuidade e a ausência de coreografia contribui para isso.

A evidência dessas intensidades é percebida pelos diretores (no momento mesmo do ato) e pelos clientes (ao assistirem ao vídeo finalizado) e relatado na linguagem de outra emoção: o medo. Segundo eles, a humilhação é real e não mais uma mera interpretação quando a escrava realmente sente 
medo tanto da dominadora como do desenvolvimento da cena. Segundo G., um dos produtores:

Há situações que acontecem em que você fica pasmo, você nem acredita, quando você vê a humilhação acontecendo de fato, seu cérebro informa que é real, que é real, o mais parecido com o real, você percebe que a menina está realmente com medo da outra, seu cérebro fica dindindindon, dá uns alertas. É aí que você começa a dirigir a dominadora: faz isso, faz aquilo, coloca mais medo nela, é aí que o filme fica show.

Na realização da humilhação, as lágrimas são transcendentais como prova do medo. Elas cumprem a mesma função dos gemidos ou da lubrificação genital do passivo sexual em uma cena pornô, e vale a pena fazer aqui esse paralelo devido à força expressiva que possuem as secreções corporais nessas práticas. As lágrimas são vistas como sinônimo de que as coisas estão correndo bem e a performance não está sendo interpretada mecanicamente. Mas há uma percepção da diferença entre dois tipos de lágrimas: aquelas que ocorrem em resposta a uma dor física e aquelas que são produto do medo dos devires da própria cena e, mais que o medo, podem tornar-se desespero. Ambas são interpretadas como reais: dor e medo (ou desespero) são duas das principais emoções que contribuem para o aparelhamento da humilhação. A terceira é o nojo.

A equipe de filmagem recebe meninas que têm nojo até de chupar um pé, o que é visto por eles como um fetiche leve. Colocar uma menina dessas para interpretar o papel de escrava em um fetiche de comer resíduos da pele ou unhas do pé, por exemplo, garante, para os produtores, que o nojo e o desespero possam chegar a um ponto elevado e que, em consequência, o filme seja real. Colocar como escrava uma menina que interpreta esses fetiches como humilhação possibilita que, na prática, a humilhação seja sentida como real.

Os graus de dor, nojo e humilhação nas escravas variam de acordo com o tipo de fetiche realizado e os estilos da interpretação. Todas as práticas têm seus desafios, mas certamente algumas precisam de maiores investimentos, tanto físicos como emocionais, ou de melhores incentivos econômicos. Não é à toa que engolir scat seja o ato mais bem pago e que, ao contrário, a submissão em um farting seja encarada pela produção mais como uma brincadeira, embora para os clientes essa brincadeira possa ser humilhante.

Se o fetiche de flatulências é encarado com risos, é porque existe uma dimensão de humor, socialmente reconhecida, em relação a isso. ${ }^{1}$ É um tipo de cena que enfoca o ânus (como no pornô), especificamente grandes ondas 
de ar saindo dali e sendo recebidas milimetricamente pelo rosto da escrava, sendo nisso que consiste a sua humilhação. Socialmente os peidos, quando não são discretos, representam uma afronta aos padrões dos bons costumes, mas mesmo assim podem ser motivo de piadas ou um ato de cumplicidade entre amigos. O fato é que nas filmagens os peidos raramente acontecem em um clima de nervosismo e medo, nem mesmo de nojo. Ao contrário, as dominadoras executam cuidadosamente a técnica de lavagem intestinal com enemas para posteriormente se encherem de ar por meio de bombinhas, e as escravas aproximam seus narizes para receber esse ar, sabendo que, paradoxalmente, esse é um ato "limpo" na prática, que não implica doses de dor física e abre poucos espaços para o imprevisível. Já o scat é outra história. Os produtores ficam satisfeitos quando conseguem gravar quatro cenas de scat por mês, pois eles conhecem as dificuldades de arranjar as escravas para esse fetiche.

É comum garotas, que algumas vezes acederam em praticar scat como escravas para a produtora, logo manifestarem negativas, preferindo interpretar outro tipo de fetiches. Se a empresa "perde escravas o tempo todo", como me foi dito, as submissas do scat são a população mais flutuante, e aquelas que conseguiram o reconhecimento de "rainhas do scat" geralmente exerciam o papel de dominadoras. O recrutamento de dominadoras, ao contrário, é "moleza": elas nem precisam mudar seus hábitos alimentícios nos dias anteriores à filmagem, somente guardar suas fezes durante alguns dias para que possam garantir à cena uma boa quantidade, usar supositórios ou injetar um pouco de água caso seja um filme de scat diarreia.

Se no discurso pornográfico mainstream o ânus é um lugar de entrada, para o fetiche de humilhação, ele é um lugar de saída. O que interessa não é a sua capacidade de alongamento e penetrabilidade como no pornô, mas seu exercício como excretor: as fezes são para o scat o que o moneyshoot (ejaculação) é para o pornô.

Existem diferentes tipos de scat, sobre os quais fala G. em seu depoimento:

Eu fiz uma série de militar, a gente coloca as meninas vestidas de militar pegando as escravas [de forma] forte por não serem obedientes. Eu botava cinco a seis minas fazendo cocô na boca de uma. De quando em quando, eu faço alguns filmes com homens, meninas cagando no homem, mas não vende tanto, é engraçado. Tem uma série que é scat polícia, a dominadora vestida de policial. Os clientes gostam de vários tipos de scat, tem dias que diarreia vende mais, outros dias é outro. Por exemplo, semana passada o que mais vendeu foi scatmilf $^{2}$ e diarreia, teens scat e dali pra baixo. Também gostam do scat só que 
é uma menina fazendo cocô sozinha; quando é assim, você pega a menina para fazer cocô várias vezes, filma rapidinho e vai guardando as cenas. Também tem clientes pedindo que faça scat com as meninas curtindo fazer, sem humilhação; este é um tipo de cena que eu não curto muito fazer, mas tem que fazer. O cliente gosta de um tipo de cocô, isso é coisa de fetichista que tem fetiche por um tipo de cocô, não pode ser pequeno, tem que ser a cota certa, mais pra diarreia.

Além do nojo envolvido na prática de scat para as escravas, no estilo da produtora esse fetiche inclui dominação e agressividade no ato. Nos casos mais extremos, a escrava é espancada ou asfixiada enquanto engole as fezes, no mais leve, é arremessada ou apenas insultada. Essa combinação de fatores faz com que a cena chegue, em não poucas ocasiões, a assumir tons de espontâneo e excessivo medo que se evidencia em lágrimas, cuspe, náuseas ou vomição. Se "o maior presente que uma rainha pode dar a uma escrava é seu mais puro caviar", em uma relação de sujeição o caviar é também a forma mais contundente de ser humilhado.

Essa real humilhação tem um enorme potencial mercantil no negócio do fetiche. Em resposta a isso, a produtora lançou uma série nova que trata da captação pelas câmeras daqueles momentos em que a dominação leva a escrava a um estágio de medo, nojo e desespero que é sentido como real. Poderíamos dizer que esse é um instante no qual se transpassa o limite entre a representação do ato e o ato mesmo. Para os produtores, esse momento é interpretado como possuidor da química da humilhação: escravas com medo real de dominadoras que - ao menos nesse instante - incorporam de modo real sua personagem.

Na divulgação dessa série é usada a expressão "choro real em tempo real". O choro é a declaração por excelência do medo e é utilizado como principal signo, inclusive em seu logo: a foto de uma mulher com olhos escorregando lágrimas. Os diretores acreditam que esta série era aquela que faltava à empresa para reafirmar entre o grupo de fetichistas e clientes que nas cenas por eles produzidas não existe espaço para a enganação. Eles se gabam de serem os melhores, graças, principalmente, a este aspecto, como me disse Samela em entrevista:

Se a gente vai fazer, faz bem. É a mesma coisa no sufocamento. Por que é que a gente vende mais que nossos concorrentes? Porque nosso sufocamento é muito mais real, o dos concorrentes é mentiroso, eles fazem uma coisa meio tipo cinema, filme de Hollywood, eles fazem que está acontecendo, mas não está. A gente é conhecida pela veracidade das coisas: tapa na cara é tapa mesmo, não é aquele tapinha fraco. Mas a gente prepara bem as pessoas para aguentar tudo isso. 


\section{Devir fissura}

O "marco teatral" permite que os espectadores experimentem sentimentos profundos sem se sentirem obrigados a intervir ou se esquivarem de ser testemunhas das ações que provocam esses sentimentos. Que não passe pela cabeça de um espectador impedir os assassinatos que ocorrem em Hamlet! E, no entanto, esses assassinatos roteirizados não são "menos reais" e sim "reais de modo diferente" do que ocorre na vida cotidiana.

Performance. Richard Schechner (2000:88)

O público não se importa nem um pouco que o combate seja ou não uma farsa e ele tem toda a razão. Entrega-se à primeira virtude do espetáculo: abolir qualquer motivo ou consequência; o que lhe interessa é o que se vê, e não o que se crê.

O mundo do catch. Roland Barthes (2009:15)

Seriam as técnicas e os aprendizados de que nos fala Samela aquilo que serviria como fronteira entre a encenação do real e o real? Ou entre a representação dos atos e os atos em si? A questão que interessa é que a interpretação de atos extremos, dentro dos moldes de um certo realismo, uma vez que passam a ser sentidos na carne (também de modo extremo), desafiam a possibilidade de pensá-los como mera interpretação. No entanto, eles são feitos no marco de uma encenação. Então, de que tipo de realismo estamos falando? Haveria ali um gesto de extrapolação de fronteiras?

Venho colocando o exercício de práticas extremas que levam as atrizes, especialmente as escravas, a atingir estados emocionais culminantes que são percebidos pelos produtores como reais e que são sentidos por elas em sua pele e traduzidos em termos de dor, nojo e medo. Tudo isso é realizado mediante técnicas, gestos, potências, atmosferas e temporalidades que operam na criação de uma estética da crueldade: a falta de um roteiro estrito que permita criar um maior grau de previsibilidade; a reiteração dos atos que se sucedem um ao outro como em efeito cascata; a ostentação do excesso explorado até a exasperação de seus significados; a declaração da impotência e a demonstração da derrota daquele que é escravizado. Como a dor é um espetáculo no universo da humilhação, é preciso que cada movimento seja evidente por si mesmo e não deixe espaço para as dúvidas. Para seus agentes, não é possível transmitir ao espectador uma ideia de realidade se as emoções não forem sentidas de modo real pelos atores. Mas volta a pergunta: de que realidade estamos falando quando, no fundo, se trata de 
uma encenação? Ou talvez a pergunta seja, pode ser uma encenação algo que é sentido como real?

Em Hacia una teoria del performance, Richard Schechner (2000) pondera que aquilo que acontece no marco teatral — o jogo da encenação — leva a uma "segunda realidade", ou a uma "realidade de modo diferente". O jogo em si, diz, não seria falso, nem débil, pois ele provocaria mudanças nos atores e no público. Esta colocação da teoria da performance me parece altamente pertinente para a interpretação de meu campo de pesquisa. Os sujeitos do mundo desses fetiches insistem na construção de um modelo de realidade, mas simultaneamente reconhecem que aquilo que eles fazem é um filme, isto é, uma encenação para a qual treinam os performers de acordo com os marcos da interpretação de personagens convencíveis. Até aqui, não seriam perceptíveis as diferenças com outros tipos de dramas do cinema, ao final, quem ganha um prêmio Oscar é aquele que mais convence o espectador do realismo de sua personagem. O plus estaria na extrapolação: em se tratando de linguagens corporais com uso excessivo da violência, os limites entre interpretação real e realidade permanecem pendurados de modo instável na corda bamba. Caberia aqui destacar uma imagem: o excesso, percebendo-o como uma das principais chaves da humilhação que auxilia no exercício da construção da realidade nessa estética.

Assim, seguindo a ponderação de Schechner sobre a "realidade de modo diferente" que se cria no espaço teatral, eu arrisco dizer que a humilhação não evoca a realidade, mas a hiper-realidade, a qual é construída e possível justamente através da encenação. Os gestos, os socos, os engasgamentos não poderiam ser reais porque a realidade somente seria plausível no plano do ordinário, no aqui, naquilo que não acontece diante das câmeras nem no repertório do ritual/teatral. Por isso, no território da encenação não haveria espaço para o real, mas sim para o hiper-real e é em função do hiper-realismo que as práticas adquirem seu tom.

Em outras palavras, essas práticas não são estritamente reais porque são encenadas. A teatralização as afastaria do repertório do snuff, do crash e de outras imagens que se definem a partir da captação de experiências de violência e abuso no plano do ordinário. ${ }^{3}$ Contudo, elas evocam esse ordinário e, não podendo ser reais, tornam-se hiper-reais (mais reais do que o real): por meio do exagero permanecem fiéis à estética da crueldade e, simultaneamente, por meio do exagero lembram ao voyeur que se trata de uma performance.

Se no universo da humilhação o excesso (de dor, medo e nojo) se aproxima do hiper-real e assim passa a ser entendido por aqueles que observam e por aqueles que produzem, isto não necessariamente se aplica a todas as 
estéticas que se baseiam na espetacularização da violência. O catch é uma prática interessante para estabelecer contrapontos pelo fato de ser - como disse Roland Barthes em seu ensaio seminal da década de 1950 sobre a França do período pós-Segunda Guerra Mundial — um espetáculo excessivo que se baseia numa estética exterior da tortura:

Aquilo que os lutadores chamam de chave, isto é, um símbolo qualquer que faz com que o lutador permaneça indefinidamente imobilizado e à mercê do adversário, tem precisamente como função preparar o espetáculo do sofrimento, de um modo convencional, portanto inteligível, e instalar metodicamente as condições do sofrimento: a inércia do vencido permite que o vencedor (momentâneo) se instale em sua crueldade e transmita ao público essa preguiça aterradora, típica do torturador e seguro da execução progressiva dos seus gestos. O catch é o único "esporte" que oferece uma imagem inteiramente exterior da tortura: esfregar violentamente o focinho do adversário impotente ou percorrer-lhe a coluna vertebral com uma força enorme e imutável, executar pelo menos a superfície visual destes gestos. Contudo, uma vez mais, trata-se apenas de uma imagem, e o espectador não deseja o sofrimento real do lutador; saboreia unicamente a perfeição de uma iconografia (Barth 2009:15).

Em artigo que faz uma releitura do texto de Roland Barthes, o literato Jaime Ginzburg reflete:

[...] essas pessoas querem ver a tortura frente a frente. Querem ter o prazer de ver um corpo fazendo outro corpo sofrer, e que esse processo seja meticuloso, inteligível, visível, exemplar [...] E os espectadores querem que tudo isso seja presenciado com intensidade, mas que nada disso seja de fato real (Ginzburg 2011:70-71).

Acredito que diferente da humilhação, no catch o excesso afastaria a estética tanto do realismo como do hiper-realismo; no final das contas, o espetáculo do sofrimento que ali se constrói é um processo exibitório no qual "as habilidades dos lutadores devem incluir, performaticamente, como condição de manutenção regular do interesse pelo espetáculo, a habilidade física de receber os golpes sem de fato serem atingidos por eles" (Ginzburg 2011:61).

Haveria, então, uma percepção clara de que o catch se trata de um teatro no qual o "importante é o que se vê e não o que se crê". Na humilhação, pelo contrário, o espectador precisa crer naquilo que observa, necessita ter fé de que cada lágrima é efeito da agonia ocasionada pela força daquele instante, pelo impacto da agressão na carne. Se para os produtores as 
técnicas são importantes porque elas garantem alguma segurança para os corpos dos performers, para os espectadores essas técnicas - cuja existência reconhecem - não precisam transparecer na cena, devem ser o mais veladas possível na procura da aproximação com o real. Assim, elas teriam uma função prática, mas não imagética.

A humilhação lembra o boxe: ${ }^{4}$ os pugilistas treinam todo tipo de técnicas, mas elas não diminuem a dor nem evitam as sequelas em seus corpos. É essa gramática da dor, no terreno do hiper-real e do excesso, que faz esses fetiches permanecerem em meio a uma pulsão para a transformação, sendo nesse sentido que estou aqui entendendo a ideia de devir.

Segundo Schechner, o drama essencial de uma performance é a transformação: enquanto os atores experimentam um rearranjo temporário de seus corpos/mentes - aquilo que o autor chamou de "transporte" — no público as transformações podem ser passageiras (entretenimento) ou permanentes (ritual): "se a transformação funciona, os espectadores individuais experimentarão mudanças de humor e de consciência" (2000:90). O que está por trás disso é a eficácia da performance. Assim, se as performances têm momentos de máxima eficácia, poderíamos aceitar que, na humilhação, a máxima eficácia se atinge através daquilo que vou chamar de fissura. Simultaneamente, a fissura seria um instante-chave de transformação tanto do drama como do corpo/mente do performer.

A fissura seria o estado, dentro da encenação da crueldade, em que a exacerbação dos roteiros cria um efeito no performer no qual são ativados os perigos subjacentes a uma prática estética do sofrimento. $\mathrm{O}$ "choro real em tempo real" do qual falei algumas páginas atrás revela um período em que são excedidos os limites da encenação, fazendo com que o hiper-real decaia e se emaranhe com o real. Dito de outro modo, a fissura seria aquele instante e espaço que nas práticas de humilhação se transpassa do consentimento ao abuso.

Para as escravas, adentrar esses fetiches é um empreendimento de risco, são prazeres perigosos tal como entende Gregori (2010). São situações e negociações delicadas nas quais nada está resolvido nem garantido de antemão. São experiências que se bem implicam prazer - e lembremos que nestes casos o prazer da escrava é evitado e negado - operam simultaneamente com tensores que podem ser transgressores, dependendo da negociação, que por momentos podem ser paródicos e que potencialmente podem se aproximar do abuso.

Essa fissura acontece nas filmagens, naqueles instantes em que a escrava sente em sua própria pele medo, angústia ou dor que não logrou prever no momento da negociação. A fissura é a evidência de que a prática 
ultrapassou a expectativa da dor, é uma pequena fenda onde o ato (ou representação do ato) se torna violência, embora logo a fissura se refaça por meio da sociabilidade que envolve a dinâmica de grupo nos sets de filmagem, isto é, a fissura acontece dentro de um ambiente controlado: o excesso nas práticas de dor e humilhação no fetiche evoca um descontrole controlado, para usar os termos de Featherstone (1995). Trata-se de uma violência regrada, em que são utilizadas técnicas corporais para suportar, mas nem por isso a prática é menos violenta. A humilhação testa os limites e nesse testar se produzem fissuras.

Os fetiches de humilhação extrema são uma encenação do hiper-real que visa provocar medo e dor, mas sem fazer tudo, pois se "tudo fosse feito" estaríamos falando de situações de ilegalidade e se romperia o pacto estabelecido entre os produtores e os clientes. Estes consomem um tipo de fantasia: quem compra sabe que não está assistindo a uma tortura real, mas exige que pareça real e, para isso, os praticantes devem fazê-la de um jeito (hiper)real. Nesse fazer, os limites entre realidade e ficção, não raramente, são rabiscados e ali se produz a fissura.

Os fetiches de humilhação são empreendimentos de risco que:

Podem colocar em perigo as normas e as convenções e, nelas, muitas das que posicionam feminilidades, masculinidades, heterossexualidades, homossexualidades e variantes entre todos esses termos. Mas podem também, dependendo das circunstâncias, transformar o que é prazer e consentimento em dor e abuso. O risco à integridade física e moral das pessoas é uma possibilidade aberta e não dada de antemão. Estudar tais manifestações permite entender como todos esses termos são abertos a negociações de sentido e de posições (Gregori 2010:4-5).

Como disse antes, reservei este artigo exclusivamente para a análise das práticas e das fissuras que acontecem em e através da humilhação. Mas, ao longo de meu trabalho, venho ponderando que a fissura não é exclusiva nem do repertório sexual, nem do universo comercial da sexualidade. É possível pensá-la em função de outras relações sociais (pais e filhos, por exemplo) e quanto aos afetos: crenças e atos sobre infringir dor e sofrimento entre os pares de um casal pelo fato de serem observadas como características inerentes ao amor. Nesses casos, a fissura pode ser percebida como uma espécie de exacerbação ou de elasticidade do limite moral, isto é, algo que pode ser desejado pelos sujeitos em certos termos e momentos, mas capaz de se tornar indesejável em outros, em um movimento micro. Não tenho espaço aqui para desenvolver esta ideia. Apenas manifesto que as fissuras no plano do ordinário não responderiam mais ao esquema que argumentei para o terreno da encenação: não é mais o hiper-real que, em sua descida 
ao abuso, se torna real. Seria um movimento, que no plano do ordinário foge de certos limites do aceito (poderíamos dizer que o deslizamento é para cima) e que também tem a capacidade de se refazer, dependendo das características afetivas dos envolvidos. ${ }^{5}$

\section{Dialogando com os feminismos}

Existe uma ideia recorrente em nossa sociedade: pornografia é sinônimo de violência, especialmente contra a mulher. Noções como opressão, submissão e abuso aparecem com frequência em nossos imaginários na hora de qualificar o mercado pornô. Essa associação tem sido objeto de profundos embates políticos ao longo das últimas quatro décadas. Tentarei contribuir para esse debate a partir dos filmes que fazem uso da gramática da humilhação. Até aqui, tenho exposto que existe um enorme leque de fetiches baseados na dupla escrava/dominadora - no qual se destacam diversos tipos de sufocações, engasgamentos, pisadas, batidas etc. — que não devem ser confundidos com as práticas S/M nem com a ideologia ao seu redor. São práticas que desafiam a possibilidade de interpretar essas representações de violência como símbolo da degradação feminina de modo literal e que, simultaneamente, nos compelem a pensar a dupla violência/prazer para além da escolha pessoal e do consentimento.

Violência, prazer e pornografia representam uma discussão de velha data inaugurada por Catharine Mackinnon e Andrea Dworkin na criação das bases do feminismo radical e no movimento antipornográfico dos anos 70. Naquele momento, organizações como Women Against Pornography (WAP), Feminist Fighting Pornography, a Nacional Coalition Against Pornography e a Women against violence in Pornography and Media atribuíram à pornografia as causas da violência contra as mulheres, os crimes de misoginia, a discriminação sexual e a propagação das desigualdades hierárquicas de gênero. Segundo esse pensamento, a submissão das mulheres se evidenciaria ao serem representadas em atos de humilhação, espancamentos, suplícios ou mostrando-as ajoelhadas fazendo sexo oral, sexo com animais ou todo tipo de cenas nas quais cabia ao corpo feminino (ou efeminado) o lugar do violentado.

A década dos 80, por sua vez, trouxe novas reflexões teóricas surgidas de outros olhares feministas que criticaram a interpretação das anteriores. Antropólogas como Carol Vance, Gayle Rubin e Pat Califia estariam na cabeceira deste pensamento. Para elas, as "antipornografias" ofereciam uma imagem simplificada do poder e uma visão rígida dos gêneros gerada no determinismo da relação dominador-dominado. A nova perspectiva desassocia 
a ideia da dominação e da coerção como modelo único relativo à sexualidade, e critica as restrições ao comportamento sexual das mulheres colocadas nos posicionamentos das feministas radicais. Nesse feminismo pró-sex, o corpo, a pornografia e o sexo poderiam ser lugares de ressignificação política para mulheres e outras minorias sexuais, e o prazer virou objeto de reflexão, assim como as maneiras alternativas e as escolhas sexuais que levam a consegui-lo. Em poucas palavras, esta postura abriu janelas preciosas para outras formas de interpretação do prazer, do erotismo e da escolha.

Contudo, um problema persistia. A antropóloga Maria Filomena Gregori (2003) já chamou a atenção para o fato de que na bibliografia do "contra-ataque" há um não tratamento do problema da violência. Isto se deve, explica a autora, à questão de que grande parte da literatura relativa a estas vertentes do feminismo se concentrou em enfatizar as práticas sexuais no terreno do lesbianismo. Tomando como ponto de partida o prazer feminino nas relações de mulher com mulher, estes estudos dão por certo que o consentimento é garantido de antemão e a violência e o perigo são transpostos para a arena dos prazeres.

Em minha pesquisa anterior (Díaz-Benítez 2010), eu tentei analisar as sexualidades das mulheres nos filmes de pornô heterossexual mainstream. Naquela ocasião, eu defendia que esse pornô dava lugar a transgressões de gênero. Ao analisar os corpos e as performances femininas nesses filmes, sobretudo aquelas que apresentavam maiores desafios cênicos, como orgias e gang bangs, eu não achava possível homens e mulheres estarem em polos tão opostos quanto dominador/dominado. Defendi que, nessa pornografia, ambos os corpos e os gêneros, masculino e feminino, eram construídos mediante uma mesma lógica do excesso, mas aquele da mulher, embora em um esquema heteronormativo, conseguia ser transgressor, isto é, da mesma maneira que os atores se apresentavam como machos hiperviris, as atrizes agiam como superfêmeas, suas figuras sendo exuberantes; as roupas e a maquiagem que utilizam reforçavam ideários aceitos de feminilidade.

Ao mesmo tempo, durante o sexo, elas transgrediam atitudes tradicionalmente identificadas com as mulheres: temperamento e gestos dóceis, delicados e até indefesos. A partir do lugar que lhes é outorgado, o do feminino (no sentido do passivo/penetrado), elas praticavam um sexo irreverente, com agência, dizendo em voz alta o que desejavam e como o desejavam. Usando expressões performativas, como "vai", "mete", "forte", "soca", explicitavam seus prazeres e desafiavam os padrões de inocência segundo os quais tem sido idealizada a sexualidade da mulher. Se, por um lado, a masculinidade excessiva dos homens se evidenciava em sua capacidade de manter a ereção por longos períodos, em penetrar vigorosa ou até violentamente, entre ou- 
tras "proezas", por outro lado, o excesso da mulher consistia justamente em suportar a penetração vigorosa ou violenta por um longo tempo e também outros tipos de práticas complexas, levando em conta que, no pornô heterossexual, no que diz respeito a estas últimas, são as mulheres que encaram os maiores desafios. Assim, nesse tipo de pornô - argumentei - o corpo e o sexo poderiam ser interpretados como lugares de ressignificação para as mulheres, uma ressignificação que, mediante o excesso e a transgressão de modelos da sexualidade feminina, simbolicamente as masculinizava.

Hoje em dia, continuo mantendo essa postura, mas com certo desconforto. Julgo que ela não rende na hora de analisar nem a relação violência/ prazer dentro das práticas sexuais do próprio pornô mainstream, nem outro tipo de sexualidades também presentes no mercado pornô, nem fetiches como aqueles da humilhação. Parece-me que eu caí na armadilha: não satanizei a violência, mas de fato, ao não problematizá-la, acabei por obviá-la. Eu não empreendi uma discussão aprofundada sobre a questão da violência no pornô, apenas chamei a atenção para a existência de outras produções heterossexuais que enfraquecem o potencial subversivo da sexualidade das mulheres e que, ao contrário, estimulam os discursos sobre a diferença entre os gêneros masculino e feminino: os filmes de estupro. Chamei aquilo de estéticas da violência, nas quais o corpo da mulher é colocado em outro lugar de enunciação, na ponta mais frágil de sua feminilidade, ao mesmo tempo em que o ideário sobre a masculinidade dos homens é levado ao extremo.

A coerção, nessas produções, configura-se como um viés que possui e produz significados estanques em relação aos valores de gênero. A esse respeito fiz uma análise bastante superficial a partir de três questões: o fato de o sexo ser sem camisinha, o fato de se tratar de sexo anal, e o fato de as atrizes do pornô se engajarem nesse tipo de cenas por escolha pessoal e, algumas, seguindo um gosto particular no que tange ao seu prazer, como pude entender em variados depoimentos que recolhi. Naqueles depoimentos, aparecia com força a noção da escolha que as feministas pró-sex colocavam tão enfática e positivamente. Insisti que valia a pena pensar que muitas mulheres não gravavam cenas de estupro por coerção, mas porque fizeram uma escolha. Assim mesmo, para muitas atrizes, a pornografia em geral pode ser não somente uma escolha feliz, mas também um projeto de vida e um mecanismo para se atingirem objetivos e ganhos econômicos mais significativos. Por que não pensar que, para outras mulheres, as cenas de violência podiam aproximá-las de seus gostos sexuais mais íntimos e satisfatórios? — indagava-me naquele momento.

Não é que hoje eu tenha mudado de opinião. O desconforto se deve ao fato de considerar que a análise continuava incipiente. Embora eu nunca 
tenha pretendido insinuar que a violência no pornô se "resolvia" devido à presença da escolha e porque algumas mulheres desfrutavam deste tipo de práticas sexuais - pois isso seria levar a violência e o perigo ao território dos prazeres, como se aquilo por si só pudesse esgotar a discussão - não consegui ir além. Este texto é uma tentativa de avançar nesse sentido.

Os filmes de humilhação extrema proporcionam outras ferramentas para pensar as dinâmicas de poder dentro do exercício da sexualidade e esta segundo a lógica comercial. Desde a insistência na comparação (sequência curta que inaugura os filmes em que dominadoras e escravas são colocadas em pé lado a lado para mostrar a diferença de tamanhos e disposições) e posteriormente na execução das práticas, esses filmes de fetiche revelam os dispositivos que permeiam nosso cotidiano, põem em cena categorias de poder hegemônico e fazem disso um espetáculo. Faço esta última asseveração conhecendo os riscos, pois discordo profundamente das pesquisas e do senso comum que interpretam certo tipo de cinema (documentário ou pornografia) ou certos exercícios sexuais ( $\mathrm{S} / \mathrm{M}$, especialmente) como representações literais da realidade social. O S/M é uma prática particularmente instigante para pensar sobre liturgias de poder e utilizar como ponto de comparação os filmes de fetiche de que trato aqui.

Uma autora cuja postura a respeito do S/M admiro é Anne McClintock. Para ela, o S/M é "o exercício teatral da condição social" (2010:217). Diz:

Afirmar que no S/M quem quer que seja o "senhor" tem poder e quem quer que seja o escravo não o tem é tomar o teatro pela realidade; é fazer o mundo andar para frente. A economia do $\mathrm{S} / \mathrm{M}$, no entanto, é a economia da conversão: de senhor em escravo, de adulto em criança, de poder em submissão, de homem em mulher, de dor em prazer, de humano em animal e, de novo, ao contrário. O S/M, como diz Foucault, "constitui uma das maiores conversões da imaginação ocidental: a desrazão transformada em delírios do coração". O S/M é o teatro da transformação: ele faz o mundo andar para trás (2010:216).

Na colocação de McClintock, um assunto que age em benefício da conversão é a paródia, questão que pode se aplicar a boa parte da pornografia e na qual é possível observar como são feitas as articulações das diferenças sociais de acordo com os moldes da paródia. Os filmes de humilhação, ao contrário, com sua insistência em uma representação crua da desigualdade e da violência, terminam por borrar seu potencial paródico. O que eu percebo é um exercício da repetição ou da lógica da perpetração, sua economia consistindo em revelar as convenções de poder em seu caráter mais nu e mais primário. O que é exibido é o que todos historicamente sabemos: que 
existe opressão dos grandes sobre os pequenos, dos ricos sobre os pobres, dos adultos sobre os menores e assim por diante.

Poderíamos pensar que a perpetração é um aparelho da paródia. Mas, nos casos desses filmes, eu me pergunto: estão mesmo parodiando? Caso estejam, surtem realmente esse efeito? Isto me leva novamente aos filmes pornôs de estupro. Como analisar violência e prazer em um filme que representa a coerção da mulher em uma de suas formas mais atrozes, que é o ataque sexual? Repito: eu não acredito que essa pornografia seja a causa do abuso e da barbárie contra as mulheres nas nossas sociedades, pois seria como pensar que quem assiste a um filme de Quentin Tarantino desenvolve vontade de matar, ou mata de fato. Mas acredito que há nessas imagens de estupro uma encenação que se pretende hiper-real e que dá poucos espaços para as negociações de sentido.

Fantasias de poder nem sempre são paródicas. A violência, a ideia de violentar ou de ser violentado por alguém atua como um agudo tensor libidinal muitas vezes no marco da hiper-realidade. E nessas fantasias ao menos especificamente as que são encenadas nos filmes de humilhação que pesquisei - o que entendemos como exercício do poder é levado ao paroxismo, nelas recriam-se os ápices da hierarquia social. ${ }^{6}$

Ela é uma encenação que exagera em seus atributos, que ostenta ações e gestos de modo enfático, e que, como o S/M, leva ao território do erotismo a tensão das diferenças e as situações de risco social (McClintoc 2010), só que em meio a uma linguagem que recusa a si mesma como "alto teatro" (2010). Lembremos quando Judith Butler (2003:198) disse: "A paródia não é subversiva em si mesma, e deve haver um meio de compreender o que torna certos tipos de repetição parodística efetivamente disruptivos, verdadeiramente perturbadores, e que repetições são domesticadas e redifundidas como instrumentos da hegemonia cultural".

Agora, não posso negar que em dois aspectos muito específicos os filmes de humilhação têm caráter disruptivo. Por um lado, a presença constante da sujeira. Já foi bem documentado por Norbert Elias a importância da anulação do imundo como ideal do processo civilizatório, como aquilo que deve ser barrado da parte visível da sociedade. Assim, torna-se relevante o fato de essas manifestações (assim como o pornô bizarro) utilizarem a sujeira para a construção de discursos eróticos a respeito de possibilidades extremas da carne (Leite Jr. 2009; Díaz-Benítez 2012). Se "a sujeira é por definição inútil, porque é aquilo que fica fora do mercado" (McClintoc 2010:230), aqui ela embasa valores sensuais e comerciais relevantes. Poderíamos pensá-la, inclusive, em termos de eróticas do nojo. Por outro lado, levando em conta que nos debates sobre a violência a pornografia tem ganhado contornos hiperbólicos que têm feito com que certas experiências sociais sejam pensadas como seus efeitos, talvez pudéssemos enxergar algum tipo de paródia 
pelo fato de aqueles filmes mostrarem a desigualdade e o abuso acontecendo em todas as esferas sociais, e não apenas no sexo. ${ }^{7}$

Eu empreendi uma etnografia com o fim de entender certos prazeres e terminei por interpretá-los através de seus perigos. Nessa humilhação, como em diversas outras práticas, prazer e perigo existem em sua convergência, em um movimento de abertura mútua. Se a fissura se revela como o ponto culminante de um empreendimento de risco (Gregori 2010), simultaneamente se revela como um ponto culminante do prazer para aqueles que observam. Embora tenha tentado entender o prazer pela fissura, não devemos pensar que esse é o único (nem mesmo o principal) prazer almejado, isto é, nem todos os sujeitos que sentem atração pelas práticas de humilhação projetam na fissura o ponto alto de seus deleites. Outros signos, disposições e enunciados pesam para a interpretação de que prazeres são aqueles que se constroem na humilhação. Finalizo resumindo brevemente:

1. Prazer pela situação. A natureza do poder e da desigualdade em si, na humilhação, se torna um gesto no qual a diferença, mas especialmente a hierarquia, é erotizada. Na leitura que Gilles Deleuze (2009) realizou sobre a obra de Masoch e de Sade, ele alega como diferença a necessidade do masoquista por relações contratuais, enquanto o sádico precisaria de instituições. No primeiro, o poder responde ao pacto, sendo negociado e executado em meio a teatralizações e encenações; no segundo, evoca-se o poder pela via da possessão. Nas estéticas da humilhação projeta-se a ideia de que não existe o consentimento do escravo para os atos que com ele se realizam e que ele é uma vítima. Tais atos aconteceriam porque o outro ostenta o poder, o domínio e a posse. Em poucas palavras, o que estes filmes revelam é um prazer pela hierarquia, daí que seja tão relevante explicitar e tensionar os diversos marcadores sociais da diferença.

2. Prazer pela dor em si, pelo sofrimento da carne. Intuo que nem sempre aquele que enxerga esses atos e os desfruta está concebendo corpos generificados, nem mesmo corpos em sua integralidade, mas fragmentos que ganham sentido através da dor: pés, boca, estômago, língua ou rosto tornam-se substâncias autônomas ligadas apenas ao seu potencial: um pé que esmaga ou é lambido, um estômago amassado, uma língua que recolhe sujeira, um rosto que recebe um soco. Fluidos e secreções vêm complementar as percepções sobre o fragmento. ${ }^{8}$

3. Prazer pelos atos corporais entre mulheres e a extrema erotização da violência quando esta acontece entre elas. Essa filmografia, arrisco dizer, poderia ser interpretada como mais uma manifestação dos modos com que a dupla violência/mulher configura um tipo de fenômeno que persiste através do tempo e das sociedades, embora mude de contexto e de modos de enunciação, existindo como um fantasma social que nos assombra e ameaça. 
4. Prazer pela espetacularização da violência e esta, por sua vez, existindo em gramáticas de demonstração, reiteração (Deleuze 2009) e excesso. Haveria aqui um prazer intrínseco pela ostentação da derrota de um diante do exercício de poder e do abuso do outro: fracasso, punição e impotência contribuem também para configurar essa estética da humilhação. Nesse sentido, valeria a pena pensar se esses filmes não integrariam um conjunto maior de espetacularizações da violência na nossa sociedade criadas na indústria do entretenimento. Faço minhas as palavras de Jaime Ginzburg (2011:72):

\begin{abstract}
A produção cultural contemporânea [...] tem insistido em uma conexão entre dor e espetáculo. Esse fenômeno está na literatura e na música, e é particularmente perceptível nas artes visuais, no cinema e na televisão [...] Cabe perguntar: por que a sociedade contemporânea admite, com intensa frequência, interesses em produtos culturais voltados para a expectativa de um gozo resultante na contemplação do sofrimento humilhante do outro como um fenômeno de espetáculo? Entre filmes de Sylvester Stallone e programas de televisão chamados indevidamente de "reality shows" (nem reality, nem shows) ou as "videocassetadas", que política tem sido estabelecida e consolidada na indústria do entretenimento, na qual a contemplação da dor é trivializada, imediatista e admitida para o consumo massivo?
\end{abstract}

5. Prazer pela humilhação excessiva. Muito tem sido escrito sobre os prazeres da dominação e da submissão, mas eu percebo que a experiência da humilhação extrema levanta questões específicas. Tento pensar estas questões a partir de uma etnografia que agora adianto com consumidores: quanto o ato voyeur é vivido como uma experiência de ressonância carnal? (Paasonen 2011). ${ }^{9}$ Quais as relações entre as fantasias colocadas nesse modo de voyeurismo e as expectativas da experiência da crueldade no próprio corpo? O que esses prazeres estariam informando não apenas sobre os limites da sexualidade, mas também sobre os limites da humanidade?

Uma coisa é importante dizer: comecei a pensar na fissura como esse momento de fronteira quando tive a oportunidade de observá-la diretamente enquanto acontecia. Mas não devemos acreditar que a fissura é exclusividade de fetiches ou de pornografias extremas. A fissura é, antes de tudo, uma possibilidade. Se na humilhação a fissura se revela quase como um devir, é porque ela joga com e nos limites da sexualidade e porque, ao ser produzida por uma indústria, ela possui enorme valor comercial. Mesmo assim, as fissuras nem sempre acontecem. Por sua vez, elas também podem vir a acontecer nos encontros sexuais mais corriqueiros e longe do mercado, como em nosso leito, inclusive se este evocar afetos e amor romântico. 
María Elvira Díaz-Benítez é professora do Programa de Pós-Graduação em Antropologia Social, Museu Nacional, UFRJ. E-mail: < blueananse@yahoo.com>

\section{Notas}

${ }^{1}$ Evandro, dono e diretor de outra das principais produtoras de fetiche na cidade comentou comigo que, diante da visita da polícia ao seu estúdio depois de uma denúncia por suspeita de atos corruptos, ele lhes mostrou dois tipos de filmes: beijos e lambidas de pés entre meninas (um feet lésbico love) e o farting. Ante o primeiro, a reação não foi de desconfiança, ante o segundo a reação foi de riso, em função do que ele foi liberado das suspeitas e de possíveis consequências.

${ }^{2} \mathrm{Na}$ linguagem pornô, as milfs são mulheres maduras. A sigla vem do inglês Mom I'd Like to Fuck.

${ }^{3}$ Filmes snuff são aqueles que, supostamente, captam assassinatos, violações e torturas em tempo real e de modo real. Digo "supostamente" porque a veracidade destas filmagens não tem sido comprovada, ao contrário, algumas delas têm sido desmascaradas como fake. No entanto, existe todo um mito ao redor do consumo e tráfico de snuff ao redor do mundo e, neste momento, muito se fala a respeito da presença desse material na deep web. O termo crash porn está sendo utilizado para a divulgação de cenas em que animais são torturados às vezes até a morte. Os gatos são os animais mais frequentes neste tipo de filmografia e, diferente do snuff que se configura mais como um mito, o crash é de fácil circulação e já tem levantado diversas críticas e denúncias ao longo do mundo. As redes sociais têm sido uma importante plataforma tanto para a divulgação desses materiais como para as denúncias contra eles. Finalmente, vale a pena mencionar os filmes caseiros que hoje em dia estão sendo conhecidos como filmes de vingança ou pornô de vingança, nos quais aparecem cenas reais, quase sempre gravadas com celular, de espancamentos dos mais variados, como adolescentes na escola, por exemplo.

${ }^{4} \mathrm{O}$ boxe, no entanto, se configura como o contrário da encenação: tudo nele é construído e percebido no âmbito do real.

${ }^{5}$ A esse respeito, ler Brazilian dancers: a travessia dos corpos em um circo norte-americano, no qual o autor, Everton Rangel (2015), realizou uma interessante análise sobre a fissura a respeito das brigas de um casal. 
${ }^{6}$ Não estou querendo afirmar com isto que, por exemplo, fantasiar com ser estuprado seja de fato desejar ser estuprado.

${ }^{7}$ Agradeço a Adriana Vianna esta última observação.

${ }^{8}$ A fragmentação do corpo faz parte da imagética pornô e guarda relação com a própria construção do fetiche quanto à valorização ou à adoração de certas partes do corpo e de objetos específicos que a ele se vinculam.

${ }^{9}$ Explico a noção com uma citação: "Ressonância descreve a força e o engate da pornografia - seu apelo visceral e seu poder para perturbar [...] A ressonância refere-se a momentos e experiências de ser movido, tocado e afetado pelo que esteja sintonizado na 'frequência certa'. Eu usei ressonância para desvendar as sensações material e visceral causadas pelos encontros com a pornografia" (Paasonen 2011:16-17).

\section{Referências bibliográficas}

BARTHES, Roland. 2009. "O mundo do catch". In: Mitologias. Rio de Janeiro: Difel / Editora Bertrand. pp. 11-23. BUTLER, Judith. 2003. Problemas de gênero: feminismo e subversão da identidade. Rio de Janeiro: Civilização Brasileira.

CALIFIA, Pat. 1994. Public sex: the culture of radical sex. São Francisco: Cleis Press.

DELEUZE, Gilles. 2009 [1967]. Sacher-masoch: o frio e o cruel. Rio de Janeiro: Editora Zahar.

DIAZ-BENITEZ, María Elvira. 2010. Nas redes do sexo: os bastidores do pornô brasileiro. Rio de Janeiro: Zahar Editores.

· 2012. "Sexo com animais como prática extrema no pornô bizarro". Cadernos Pagu, 38:241-279.

· 2014. "O sexo é sempre culpável? Notas sobre prazeres, perigos e fissuras na sexualidade". Folha de Gragoatá Jornal dos alunos de Antropologia da UFF. Disponível em: http://afolhadogragoata.blogspot.com.br/2014/06/o-sexo- -sempre-e-culpavel-notas-sobre.html. Acesso em 21 de novembro de 2014.

FACCHINI, Regina. 2008. Entre umas e outras: mulheres, (homo)sexualidade e diferenças na cidade de São Paulo. Tese de Doutorado em Ciências Sociais, IFCH, Unicamp.

FEATHERSTONE, Mike. 1995. Cultura de consumo e pós-modernismo. São Paulo: Studio Nobel.

GARCIA, Esteban. 2009. "Políticas e prazeres dos fluidos masculinos: barebacking, esportes de risco e terrorismo biológico". In: Maria Elvira Díaz-Benítez \& Carlos Fígari (orgs.), Prazeres dissidentes. Rio de Janeiro: Editora Garamond. pp. 537-566. GINZBURG, Jaime. 2011. "Tortura como espetáculo". In: Heidun Krieger Olinto \& Karl Erik Schollhammer (orgs.), Literatura e realidade(s). Rio de Janeiro: Editora 7Letras. pp. 58-74.

GREGORI, Maria Filomena. 2003. "Relações entre violência e erotismo". Cadernos Pagu, 20:87-120. 
2004. "Prazer e perigo: notas sobre feminismo, sex-shops e S/M". In: Adriana Piscitelli; Maria Filomena Gregori \& Sergio Carrarra (orgs.), Sexualidades e saberes: convenções e fronteiras. Rio de Janeiro: Editora Garamond. pp. 235256. . 2010. Prazeres perigosos: erotismo, gênero e limites da sexualidade. Tese de livre docência, Departamento de Antropologia, Universidade Estadual de Campinas.

LEITE Jr., Jorge. 2009. "A pornografia 'bizarra' em três variações: a escatologia, o sexo com cigarros e o 'abuso facial'". In: Maria Elvira Díaz-Benítez \& Carlos Eduardo Fígari (orgs.), Prazeres dissidentes. Rio de Janeiro: Garamond. pp. 509-536. LINDER, Evelin Gerda. 2001. "Humiliation and the human condition: mapping a minefield". Human Rights Review, 2(2):46-63.

MACKINNON, Catharine. 1993a. "La pornografía no es un asunto moral". In: Catharine Mackinnon \& Richard Posner (orgs.), Derecho y pornografia. Bogotá: Universidad de los Andes-Siglo del Hombre Editores. pp. 45-86. - 1993b. Only words. Cambridge: Harvard University Press.

MACKINNON, Catharine \& DWORKIN, Andrea. 1988. Pornography and civil rights: a new day for women's equality. Minneapolis: Organizing Against Pornography. McCLINTOCK, Anne. 1993. "Maid to order. Commercial S/M and gender power". In: Pamela Church \& Roma Gibson (orgs.), Dirty looks. Women, pornography, power. London: British Film Institute. pp. 207-231.

- 2010. Couro imperial: raça, gênero e sexualidade no embate colonial. Campinas, SP: Editora Unicamp.

MILLER, William Ian. 1995. Humiliation and other essays on honor, social discomfort and violence. Ithaca, NY: Cornell University Press.
- 1999. Anatomia del asco. Madri: Grupo Santillana Editores.

PAASONEN, Susanna. 2011. Carnal resonance. Affect and online pornography. Cambridge: The Massachusetts Institute of Technology Press.

PERLONGHER, Nestor. 1987. O negócio do michê: prostituição viril em São Paulo. São Paulo: Brasiliense.

RANGEL, Everton. 2015. Brazilian dancers: a travessia dos corpos em um circo norte-americano. Dissertação de Mestrado em Antropologia Social, Museu Nacional, Universidade Federal do Rio de Janeiro.

RUBIN, Gayle. 1984. "Thinking sex: notes for a radical theory of politics of sexuality". In: Carol Vance (org.), Pleasure and danger: exploring female sexuality. Nova York: Routledge. pp. 267-293. . 2001. "The catacombs: a temple of the butthole". In: Deviations. Durham \& London: Duke University Press. pp. 224-240.

SAEZ, Javier \& CARRASCOSA, Sejo. 2012. Por el culo. Políticas anales. Madrid: Egales.

SCHECHNER, Richard. 2000. Performance: teorías y prácticas interculturales. Buenos Aires: Universidad de Buenos Aires.

VANCE, Carol. 1984. Pleasure and danger: exploring female sexuality. Nova York: Routledge. 


\section{Resumo}

Humilhação ou humiliation porn é um segmento do mercado do fetiche que reúne uma diversidade de práticas que usam a dominação, os espancamentos, os engasgamentos e as sufocações em gramáticas comerciais de dor, medo e nojo. Estas, articulando marcadores sociais da diferença, são quase sempre realizadas em duplas de mulheres que representam a relação dominadora / escrava. O objetivo deste artigo é o exame das formas com que a violência atua no erotismo, ou melhor, os modos, no âmbito do erotismo, com que se intersectam o prazer e o perigo. A partir do exame das práticas me pergunto: quais são os limites entre a representação dos atos e os atos em si? Desenvolvo a categoria fissura para analisar a questão. Palavras-chave Humilhação, Fetiche, Fissuras, Excesso, Sexualidade.

\section{Abstract}

Humiliation porn is a segment of the fetish market that includes a variety of practices that uses domination, spanking, choking and suffocation in commercial grammars of pain, fear and disgust. Articulating social markers of difference, these almost always feature women pairs who act out the dominatrix / slave relationship. This article aims to investigate how violence acts in eroticism, or, to be more precise, how pleasure and danger intersect in erotica. Through an examination of these practices, the article asks: what are the limits between the representation of the acts and the acts themselves? The notion of fissure is developed in order to answer the question. Key words Humiliation, Fetish, Fissures, Excess, Sexuality. 